${ }^{3}$ Goldstein SL. Ventricular opacification secondary to rupture of intracranial aneurysm during angiography. $J$ Neurosurg 1967; 27:265-7.

${ }^{4}$ Hoff JT, Potts DG. Angiographic demonstration of haemorrhage into the fourth ventricle. J Neurosurg 1969;30:732-5.

${ }^{5}$ Waga S, Kondo A, Moritake K, Handa $\mathrm{H}$. Rupture of intra cranial aneurysm during angiography. Neuroradiology 1973;5:16973.

${ }^{6}$ Lin JP, Kricheff II, Chase NE. Blood pressure changes during retrograde brachial angiography. Radiology 1964;83:640-6.

${ }^{7}$ Shibuya S, Igarashi S, Amo T, Sato H, Fukumitsu T. Mycotic aneurysm of the internal carotid artery. $J$ Neurosurg 1976;44:105-8.

${ }^{8}$ Harrison MJG, Hampton JR. Neurological presentation of bacterial endocarditis. $\mathrm{Br}$ Med J;2:148-51.

9 Jones HR, Siekert RG, Geraci JE. Neurologic manifestations of bacterial endocarditis. Ann Int Med 1969;71:21-8.

${ }^{10}$ Bohmfalk GL, Story JL, Wissinger JP, Brown WE. Bacterial intracranical aneurysm. $J$ Neurosurg 1978;48:369-82.

11 Ghoshhayra K, Scotti L, Marasco J and Baghai-Naiini P. CT detection of intracranial aneurysms in subarachnoid haemorrhage. $A J R$ 1979;132:613-6.

${ }^{12}$ Inoue Y, Saiwai S, Miyamoto T, et al. Postcontrast computed tomography in subarachnoid haemorrhage from ruptured aneurysms. $J$ Comput Assist Tomogr 1981;5(3):341-4.

${ }^{13}$ Frazee JG, Cahan LD, Winter J. Bacterial intracranial aneurysms. $J$ Neurosurg 1980;53:633-41.

\section{Levodopa induced chorea in Meige} syndrome

Sir: Meige syndrome is an adult-onset focal dystonia which affects the face and jaw causing blepharospasm and painful oromandibular spasms. ${ }^{1}$ No histological or neurochemical abnormalities have been found, but some clinical pharmacological studies point towards a striatal dopamine preponderance. ${ }^{2}$ We report here the occurrence of levodopa-induced peak dose chorea in a patient with Meige syndrome.

A 44-year-old right-handed woman with no antecedent medical, psychiatric or drug history and no family history of neurological illness, developed writer's cramp shortly after her promotion to supervisor of a typing pool in 1972. Her disabilities were initially mild, but gradually increased to encompass other dexterous tasks such as unscrewing bottle tops and holding a badminton racket. In October 1981 she resigned from her job because she was finding it too mentally taxing and within two weeks, intermittent blepharospasm had developed. One month later her mother, who had a long history of depression, committed suicide and within days of this, intermittent yawning move- ments and tonic jaw spasms also appeared. Over the next three months symmetrical involuntary facial dystonia became increasingly distressing. At times she was unable to read, type or watch television without developing intense blepharospasm; bright lights were another powerful trigger. The jaw contractions on the other hand, were adversely affected by emotional upsets. Her personality and temperament were normal and there were no overt features of depression. In addition to paroxysms of uncontrollable sustained eyelid closure, facial spasm and trismus, the platysma and right-sided neck and shoulder muscles were occasionally involved causing neck torsion and shoulder elevation. Posture of the right arm was normal at rest and when outstretched, but the limb adopted a typical dystonic posture when writing. Cogwheel rigidity was detectable at the right wrist on synkinesis and there was a decreased right arm swing when she walked. Normal investigations included cerebrospinal fluid examination, electroencephalography and computed tomography. Treatment was begun with levodopa (100 $\mathrm{mg}$ ) in combination with benserazide ( 25 mg) administered in two divided daily doses. The dose was increased over ten days to $100 \mathrm{mg}$ of levodopa eight-hourly in combination with a peripheral decarboxylase inhibitor. After three weeks, chorea appeared in the fingers of the right hand and rapidly spread to involve the whole of the right arm. The right-sided painful stiffness was abolished, but the dystonic facial and jaw spasms increased in severity and levodopa was discontinued. The druginduced chorea then subsided rapidly over forty-eight hours, but she became markedly depressed and improvement in her dystonia occurred only slowly over several weeks. Her right-sided rigidity was subsequently alleviated by benzhexol $2 \mathrm{mg}$ twice daily without benefit to the dystonia.

The occurrence of levodopa-induced dyskinesias provides circumstantial evidence implicating dysfunction of the basal ganglia in focal dystonias. The modest aggravation of the facial spasms would also be in keeping with the notion of a relative dopaminergic excess in the corpus striatum. It is of interest that, in contrast, dopamine receptor agonists have been reported to be of benefit in both Meige syndrome ${ }^{3}$ and levodopainduced end-of-dose focal dystonia in Parkinson's disease. ${ }^{4}$

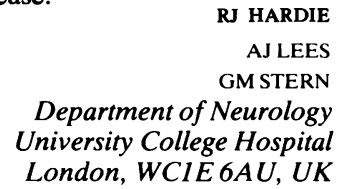

Accepted 20 October 1982

\section{References}

1 Meige $\mathrm{H}$. Les convulsions de la face-une forme clinique de convulsion faciale, bilatérale médiane. Rev Neurol (Paris) 1910; 20:43743.

2 Tolosa ES, Lai C. Meige disease: striatå dopaminergic preponderance. Neurolog (Minneap) 1979;29:1126-30.

3 Micheli F, Pardal MMF, Leiguarda RC. Beneficial effects of lisuride in Meige disease Neurology (NY). 1982;32:432-4.

4 Lees AJ, Stern GM. Bromocriptine in treatment of levodopa-induced end-of-dose dystonia Lancet 1980;2:215-6. 